Sir George ended by saying that he had sufficient confidence in the ingenuity of electrical engineers to believe that, since no fundamental reason had been found in ten years which made a fusion reactor impossible, this amounted to proof that it could be made.

Among the topics raised in the discussion after the talks was the possibility of using thermonuclear neutrons for breeding fissile material, and the point was made that this might be worth while even if the thermonuclear reaction cycle itself was not selfsustaining. It is, however, too early yet to say how this would compete with 'conventional' breeder systems.

Asked whether power might be achieved using the 'cold fusion' process, whereby the hydrogen and deuterium nuclei in a mesic molecule coalesce and fling out the meson with high energy, Mr. Lawson said that it was unlikely that a meson, suffioiently long lived to make such a process economical, existed. It was agreed, however, that this was a very interesting phenomenon, and showed that quite unexpected things may still happen.

The discussion was not entirely satisfactory, how ever, since some of the most interesting questions could not be answered for reasons of security. There is no doubt that Prof. Cowling echoed the feelings of the meeting when he said, in thanking the speakers, that he looked forward to the day when it would not be necessary to answer questions by referring only to the latest published information.

J. D. LaWSON

\title{
THE DEFENCE RESEARCH BOARD, CANADA
}

\section{By C. A. POPE}

$T$ HE Defence Research Board, Canada's largest scientific organization, celebrated its tenth anniversary recently.

During the later stages of the Second World War, the efforts of Canadian scientists indicated that research could provide vitally important support to the Armed Forces; and the desire of the National Research Council and other scientists involved to return to civilian research pursuits made obvious the creation of a permanent defence research organization. Hence was born the Defence Research Board on April 1, 1947. The first chairman was Dr. Omond M. Solandt, a youthful, war-time operational research scientist, who was succeeded in March 1956 by Dr. A. Hartloy Zimmerman, previously a member of the Defence Resoarch Board and vice-chairman of the organization for about a year.

The Board is believed to be unique as a scientific body because it is directed by civilians although integrated within the Department of National Defence, and it has surmounted successfully a series of growing pains and has achieved international recognition for its efforts on behalf of defence research.

Among the problems overcome during the first ten years of the Board's existence were the initial phase of organization, the establishment of a carefully planned scientific programme-interrupted by urgent Korean War requirements-and a widesproad re-organization following the end of hostilities with emphasis on now and increasingly important military fields.

The keystone of defence science in Canada is the Defence Research Board itself, which consists at present of fourteen members, six of whom are ex-officio and six of whom represent Canadian science both from tho universities and from industry. The chairman and vice-chairman are permanent, salaried members of the Board. The chairman is appointed by the Governor-General-in-Council; his status is that of a chief of staff and, as such, he sits on the Chiefs of Staff Committee. He possessos many of the financial and other powers of a deputy minister, since he reports directly to the Minister of National Defence.
The Board operates with three main objectives in mind : (1) To use existing Canadian research and development facilities wherever possible to meet the neods of the Armed Forces. (2) To maintain collaboration with the United Kingdom and United States on a partnership basis. (This permits the Board to concentrate its efforts on a limited number of problems of particular importance to Canada or for which Canada possesses unique resources or facilitios.) (3) To promote in every way possible the progress of standardization, a subject of vital Canadian concern.

The value of the Defence Research Board's physical assets, comprising mainly eleven well-equipped pormanent scientific laboratories, totals about $32,000,000$ dollars. Almost 4,500,000 dollars was invested in the facilities which existed at Valcartier, P.Q., and Suffield, Alta., when they were Armed Services' establishments prior to 1947 . Now construction during the past decade, therefore, at these and at the Board's other establishments represents a total expenditure of about $27,500,000$ dollars. The resulting modern research facilities will help to serve for many years to come the defence scientific interests of Canada.

The total appropriation requested for defence research and development in 1956-57 was almost $80,000,000$ dollars, of which approximately $24,000,000$ dollars will be used for research. This sum covers the operational costs of the Board's establishments and its liaison offices in London and Washington, and its annual 1,000,000 dollars for its programme of grants and contracts for fundamental research with Canadian universities. The remainder of the appropriation covers the development activities of the three Services.

The staff of the Defence Research Board has increased from a handful of scientists, seconded Service officers and administrative personnel early in 1947 to $a$ total of 2,800 , of whom 650 are employed in professional categories. In addition, scientists and others with highly specialized knowledge from the scientific community sit voluntarily in consulting capacities on a wide variety of panels and committees concerned with the Board's programme. 
The investigations carried out by the Defence Research Board involve a variety of scientific disciplines and fields. The research areas concerned include geophysics and the Arctic, electronics and telecommunic ations, medical and environmental protection, materials, aeronautics, civil defence, operational research and guided missiles. Studies and appraisals of equipment and weapons of the three Armed Services are maintained on a continuous basis with the view of developing new items and improving existing ones.

The Board's naval rasearch activities are carried out at the Naval Research Establishment and the Pacific Naval Laboratory in Dartmouth, N.S., and Esquimalt, B.C., respectively. The weapons programme is concentrated at the Canadian Armament Research and Development Establishment at Valcartier, P.Q., and investigations in the methods of protection against animal diseases are carried out at a small establishment on Grosse Ile in the St. Lawrence River near Quebec City.

In Ottawa, the Defence Research Telecommunications Establishment and the Defence Research Chemical Laboratories are just beyond the eastern and western approaches to the city, respectively. Headquarters activities are carried out at National Defence Headquarters, where an Operational Research Group is also co-ordinated with the Defence Research Board Services programme in this new scientific field.

The Board's biological research programme is conducted at the Defence Research Kingston Laboratory in Kingston, Ont., and its medical activities at the Defence Research Medical Laboratories at Downsview, Ont. The latter establishment is concerned with investigating methods of using the Serviceman's physical capabilities to their fullest extent and with matching them to the complex machines he operates, rather than with curing the ill.

Activities at the Defence Research Northern Laboratory at Fort Churchill, Man., involve Arctic research. Until recently, emphasis was placed on developing techniques and methods of assisting troops to operate effectively under severe weather conditions. Cold-weather trials involving both men and equipment have been particularly important fields for study. The Laboratory now provides facilities for visiting scientists from Canada, the United Kingdom and the United States engaged in conducting northern investigations. During the next two years, the Laboratory will serve particularly as a scientific base for many of Canada's International Geophysical Year operations. Scientists of the Board will assist an American rocket team in launching a series of missiles with instrumented nose cones in support of upper atmospheric reseerch.

At Suffield, Alta., near Medicine Hat, staff scientists conduct trials and experimental activities connected with the defensive aspects of biological, chemical and flame warfare. An important entomological programme, completed recently, resulted in the development of useful methods of controlling forest and crop pests by air-spray techniques. The station is ideally located on the prairies for trials and experiments, and its thousand square miles of rolling terrain provide unsurpassed physical facilities for such operations.

The Board has gained international recognition for some of its scientific activities, several of which promise useful civilian implications. Among these are anti-corrosion techniques to protect ships' hulls, a rocket-type anti-tank weapon with impressive accuracy, development of the detection unit installed in the Mid-Canada Early Warning Line, upper atmospheric research, development of ration and survival packs and dehydrated food techniques and an active role in promoting in Canada knowledge of guided missiles.

Recent changes in emphasis in the Board's scientific programme have involved an increasing interest in atomic activities, including the participation by members of its staff in last year's British-Australian atom bomb trials, an expanding use of electronic aids in many fields of defence science and in co-operation with the United Kingdom and the United States, a series of studies concerning certain phases of the defence against intercontinental ballistics missiles and, particularly, methods of countering attacks by such weapons.

The work achieved by scientists of the Defence Research Board during the past ten years provides them to-day with the confidence necessary for their second decade of operations.

\section{OBITUARY}

Mr. Atholl Blair, C.B.E.

Mr. Atholl Blatr died suddenly at his home in Belfast last month at the age of seventy-one. He had spent a lifetime in the service of Messrs. Harland and Wolff, and was probably the world's leading builder of all forms of marine propelling machinery. When he retired in 1953 from the firm with which he had served his apprenticeship as an articled pupil he occupied the position of engine works manager and was a director of the firm. His services were retained as a consultant, however, and he remained a most active man until his sudden death.

Atholl Blair was the son of the late Sir Robert Blair, a distinguished educational administrator who occupied the position of chief education officer to the London County Council. Before succeeding to that appointment Sir Robert had gone to Ireland at the turn of the century to set up the system of technical education in that country, and his son Atholl, after going to school in Edinburgh and Dublin, attended the City and Guilds Engineering College, where he studied under the late Prof. Dalby.

With this background it is not surprising that Mr. Blair at all times took a keen interest in technical education, and it is characteristic of the man that, long before industry began to show its present concern in this vital activity, Mr. Blair was much occupied in it from the point of view of his apprentices and of their welfare. He was the first chairman of the Joint Committee for the award of National Certificates in Northern Ireland and later became a member of the Committee of the Belfast College of Technology.

Atholl Blair's professional career was a most impressive one. His contribution to the national 